\title{
Volta ao mundo por ouvir-dizer: Redes de informação e a cultura geográfica do Renascimento
}

Plínio Freire Gomes ${ }^{1}$

RESUMO: Este artigo elucida que, ao privilegiar a observação, a curiosidade e a busca de aprimoramento intelectual, a cultura do Renascimento é um fator determinante na criação do viajante moderno. Outra peculiaridade do período reside na transformação do conhecimento geográfico em foco de interesse estratégico. Mas o segredo oficial, preservado pelas "casas de contratação", passou por um contínuo processo de corrosão. A necessidade das Coroas ibéricas de ratificar a posse sobre os novos territórios coloniais tornava a divulgação tão importante quanto o silêncio. Além disto, a experiência dos Descobrimentos foi assimilada por informantes de segunda-mão e transmitida através de canais diplomáticos e comerciais, numa trama que se ramificou por toda Europa. Tal organismo coletivo e não-oficial, que hoje chamaríamos de "rede", colocou dados relativos à Ásia, África e América à disposição dos cosmógrafos, e constituiu assim o núcleo fundamental da cartografia quinhentista. $\bigcirc$ artigo tenta mostrar que o fluxo do saber geográfico no período dos Descobrimentos caracterizou-se pela prática quase irrestrita da cópia e pela configuração informal e internacional do seu circuito de consumo.

PALAVRAS-CHAVE: Descobrimentos. Cosmografia. Política de Segredo. Propaganda. Cartografia quinhentista. Redes de conhecimento informais. Historia da cartografia.

ABSTRACT: This paper shows what an important role Renaissance culture played in shaping the mindset of modern travelers thanks to its focus on observation, curiosity and the pursuit of intellectual refinement. Another peculiarity of this historical period is the use of geographic knowledge for strategic purposes. However, the official secrets, homologated by the Casas de Contratación (entities set up by Spain to control colonial trade), went through a continuous process of corrosion. The need of the Portuguese and Spanish Crowns to ratify their possession of new colonial territories made the disclosure of such information as important as silence. Furthermore, the experience of the Discoveries was assimilated by second-hand informers and shared through diplomatic and commercial channels that branched out across Europe. This collective and non-official organism - or "network" as we might call it today - made data
1. Doutorando do Instituto Europeu de Florença. E-mail: $<$ gplinio@hotmail.com> 
2. "Quem quer andar por aí, que ande: / veja Inglaterra Hungria, França e Espanha; / o que eu gosto é de habitar a minha província $[. .$.$] / Isto$ me basta; o resto da terra, sem nunca pagar pedágio, irei buscando / com Ptolomeu, esteja o mundo em paz ou em guerra: / e todo o mar, sem fazer votos quando / lampeje o céu, seguro sobre as cartas / verei mais que sobre lenhos, balançando." Tradução livre do autor. relative to Asia, Africa and America available to cosmographers, thus constituting a firm basis

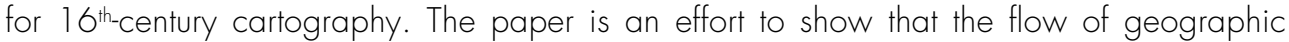
knowledge during the Age of Discoveries was characterized by a virtually unrestricted practice of copying and by a circuit of consumption that was both informal and international.

KEYWORDS: Discoveries. Cosmography. Secrecy policy. Propaganda. 16 th-century cartography. Informal knowledge networks.

"Chi vuole andare a torno, a torno vada: vegga Inghilterra, Ongheria, Francia e Spagna; a me piace abitar la mia contrada [...]

Questo mi basta; il resto de la terra, senza mai pagar l'oste, andrò cercando con Ptolomeo, sia il mondo in pace o in guerra: e tutto il mar, senza far voti quando lampeggi il ciel, sicuro in su le carte verrò, più che sui legni, volteggiando."

ARIOSTO, Satire (III: 55-66)

A épica dos Descobrimentos saturou nossa fantasia com os feitos de Colombo, Vespucci e Magalhães. Ainda hoje nos encanta pensar naqueles homens que embarcaram em caravelas vacilantes para constatar, a olhos vistos, a existência de outras terras. Mas houve quem preferiu ficar para trás e, como Ariosto, só conheceu o mundo através da extensa, minuciosa e segura viagem dos mapas. À sua maneira, essa gente também "descobriu" a América.

Depois de ser visitada por um punhado de navegantes, o Novo Mundo acabou por insinuar-se na consciência de um público bem mais amplo. Tal passagem não foi nem transparente nem óbvia. Fundado no compromisso entre o ouvir-dizer e o compreender, esse outro "descobrimento" pouco tinha em comum com a realidade sensível do território (o clima, as matas, as gentes). As impressões de viagem que coloriam o relato daqueles aventureiros vindos de tão longe não demoraram a desencadear um tortuoso processo de vulgarização. As novas terras que hoje chamamos "América" passaram assim a ser traduzidas em categorias, perspectivas, estereótipos, classificações, generalizações. Em síntese, foram assimiladas a um conhecimento geral sobre os confins do mundo.

É preciso ter claro que este tipo de saber refletiu tensões de natureza claramente histórica. A visão da América (bem como de outras possessões ultramarinas), que começava agora a tomar forma, entrelaçou vários níveis de interesse, estando sujeita a dinâmicas culturais complexas. Ela resultou, em parte, de políticas oficiais que visavam a acumulação e o controle de informações consideradas estratégicas. Mas também se amalgamou a um patrimônio mental coletivo, despertando curiosidades, causando admiração e espanto, animando projeções utópicas.

Não há como interpretar o discurso renascentista sobre os Descobrimentos 
sem levar em conta os meios de produção e difusão do saber geográfico. $\bigcirc$ presente artigo tem em vista as relações de força estabelecidas entre diferentes circuitos de consumo de bens culturais. Meu enfoque irá privilegiar uma rede bastante dilatada de transmissão de dados que interligava três diferentes matrizes envolvidas na tarefa de investigar a superfície do globo e suas novas configurações: a) a vigilância centralizadora de poderes institucionais envolvidos com a conquista, b) o assédio indiscreto das potências concorrentes e c) o interesse de um amplo público de curiosos.

Viajantes e cosmógrafos

Um século antes das primeiras navegações ibéricas, certos humanistas parecem descobrir um atrativo novo em epopéias como as de Ulisses e Enéas. Mais que a coragem e a sagacidade, é o movimento, a transmigração dos personagens por horizontes longínquos a encantar os leitores mais exigentes. Petrarca, por exemplo, exalta o destino aventuroso de quem partia por mar e por terra para atender à "ânsia inata de ver lugares novos". Evoca também Homero, com seu bastão de trovador cego a perambular de corte em corte, e o define como um "homem perfeito". Vagamundos como ele, conclui o poeta, seriam os únicos a se deslocarem com o corpo e com a mente, conseguindo assim aprender em toda parte algo de inusitado ${ }^{3}$. Tais concepções são representativas da virada cultural que caracteriza a passagem do viator medieval para o viajante moderno. Antes a ideia de movimento era associada à peregrinatio, segundo a qual o fiel reconhecia a vida terrena como exílio da alma e partia numa viagem em busca da transcendência ${ }^{4}$. Agora a mesma ideia começa a remeter a uma vontade de saber que tinha muito de profano e que, fundamentalmente, simbolizava a vitória do homem sobre a ignorância. Neste contexto a espiritualidade do viajante contava menos que seu senso de observação, pois o mero ato de vencer distâncias transformara-se em fonte de conhecimento.

Ocorre que, na Renascença, celebrar a viagem era fácil; viajar, nem tanto. Como se dava, então, a "ciência" do mundo? Quem estabelecia os critérios do testemunho geográfico? Quais eram seus meios de difusão e quais os seus limites?

Os humanistas foram, e aqui retomo os versos citados na epígrafe, criaturas essencialmente sedentárias. É curioso pensar que Ariosto, cujos personagens não cansam de criar artifícios náuticos e aeronáuticos, confessasse ter aversão, para não dizer fobia, às viagens. Afinal, em Orlando Furioso, a erudição cosmográfica assume um papel narrativo determinante, como se pode observar na passagem sobre a navegação de Astolfo ao Oriente ${ }^{5}$ e na viagem do mesmo à Lua, no que vem a ser uma das primeiras explorações espaciais da história da literaturab . $\bigcirc$ fato é que na série de versos reunidos nas Satire, o poeta
3. Numa carta ao doge Andrea Dandolo, Petrarca fala de sua paixão pelo viajar; apud C. Trinkaus (1976, p. 6).

4. Ver Gerhart Ladner (1967).

5. Ver canto XV, em Ludovico Ariosto (1966), consultado na versão eletrônica Letteratura Italiana Zanicbelli (v. 1, pp. 323-349).

6. Idem, canto XXXIV, 70. e ss (v. 2, pp. 258-280). Há edição brasileira bilíngue em que consta a viagem de Astolfo à lua a partir da oitava 72. Cf. Ludovico Ariosto (2002). 
7. Ludovico Ariosto (1954), sempre na versão eletrônica "Letteratura Italiana Zanichelli”, pp. 21-29 e pp. 53-57.

8. Ver W. Robert KARROW (1993); e, ainda Hildegard Binder Johnson (1963, p. 87) faria uma apologia à vida apartada e meditativa que, nas composições III e VII, contrapunha-se justamente às asperezas do viajar? ${ }^{7}$. E Ariosto estava longe de ser - único a preferir a segurança dos mapas a enfrentar pedágios e tempestades fora da província natal. $\bigcirc$ maior vulgarizador da travessia de Colombo, o lombardo Pedro Mártir Anghiera, é um caso exemplar. Estudioso sério, teve o cuidado de coligir dados oficiais com relatos de homens do mar e, provavelmente, foi o primeiro a intuir que a terra firme reinvidicada pelos espanhóis não era a Ásia e sim outro continente, um "Novo Mundo" - o certo, porém, é que jamais colocou os pés nele. A regra também vale para três dos maiores cartógrafos da época. Lorenz Fries, compilador de mapas e de prognósticos astrológicos, privilegiava o saber de Ptolomeu ao dos modernos, e tudo leva a crer que morreu sem ter visto um oceano de verdade (Figura 1). O grande editor de planisférios Grüninger nunca se afastou da zona de Frankfurt. E o próprio Martin Waldseemüller, tão reputado pelos conhecimentos geográficos quanto pela fineza do seu latim, jamais viajou nem mesmo para a ltália8 (Figura 2).

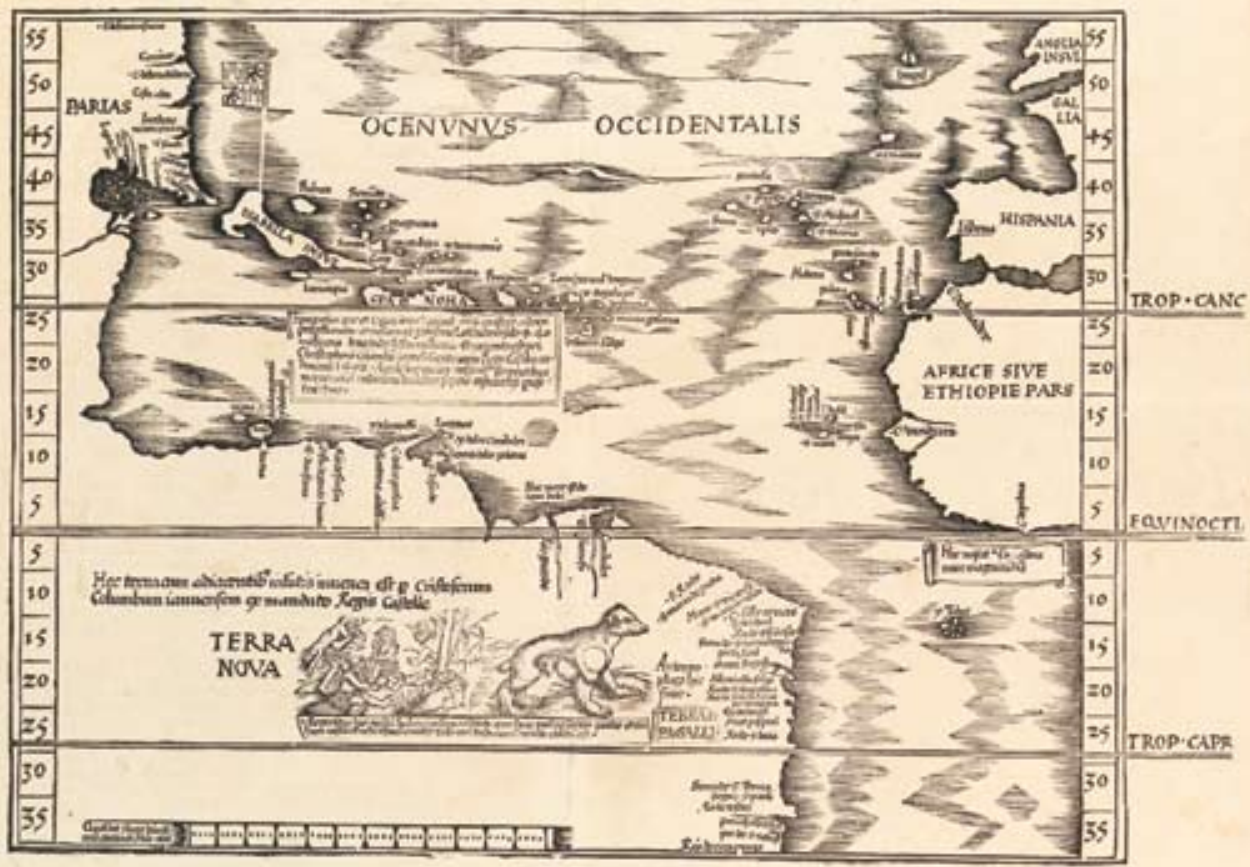

Figura 1. Terra Nova, Lorenz Fries e Martin Waldseemüller, 1541, xilogravura. Instituto de Estudos Brasileiros / USP (acervo depositado temporariamente pela Justiça Federall), São Paulo. 


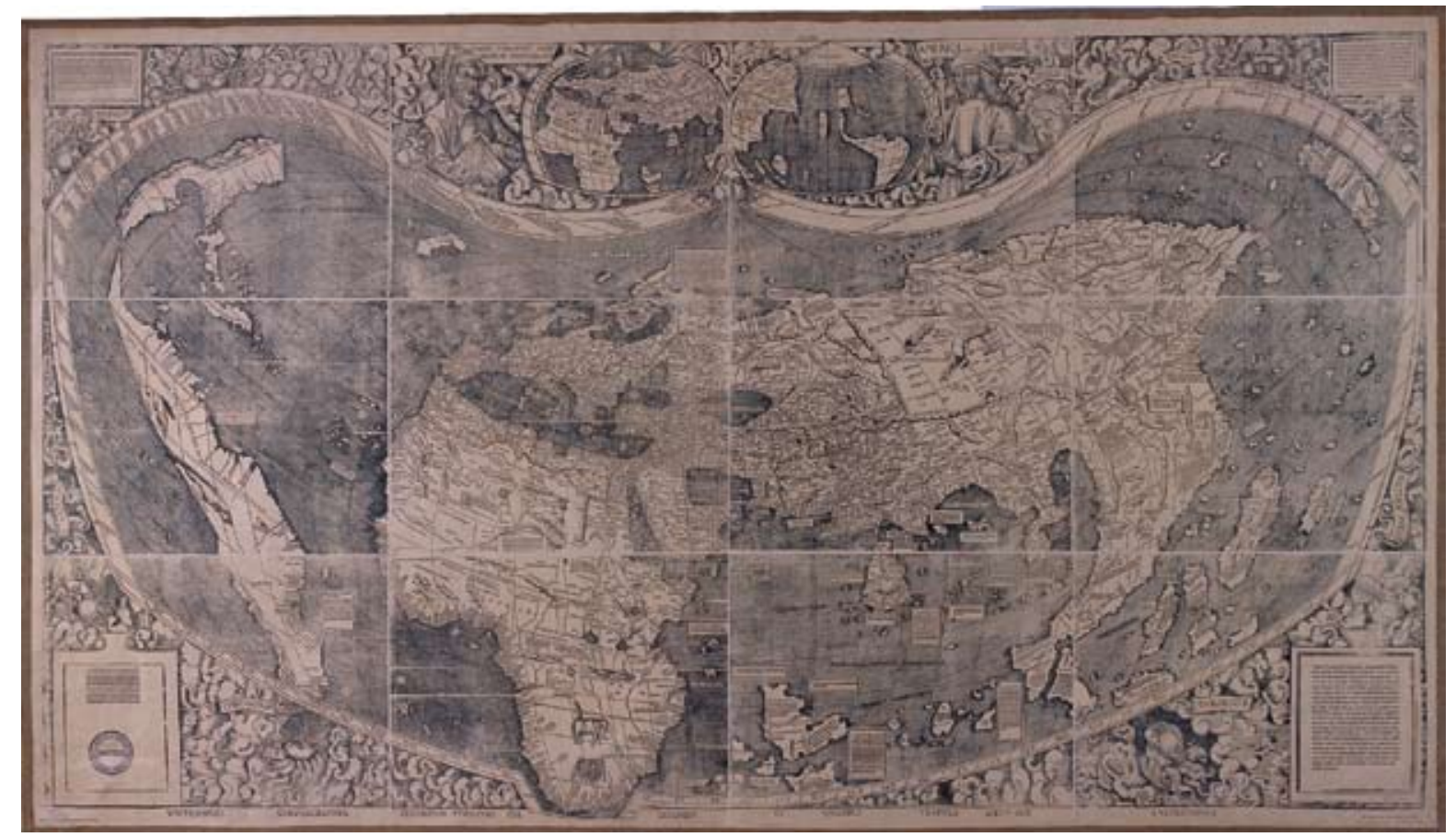

Figura 2 - Universalis Cosmographia, 1507. Martin Waldseemüller, Estrasburgo. Reprodução fac-símile de exemplar gravado sobre madeira. Mapoteca do Itamaraty, Rio de Janeiro.

Eram incontáveis os viajantes imaginários que contemplavam os prodígios da Criação sem sair de suas bibliotecas. Mas na estirpe dos humanistas também houve viajantes autênticos. Antes de se dedicar à edição de relatos de viagem, o veneziano Giovanni Battista Ramusio visitou o Egito e a Terra Santa. milanês Girolamo Benzoni viveu quatorze anos na América, participando em expedições no México, Peru, Venezuela, Colômbia e América Central. Já Gonzalo Fernández de Oviedo realizou nada menos que doze travessias do Atlântico e sua permanência nas Índias soma bem cinquenta anos, durante os quais realizou as primeiras observações naturalistas no Novo Mundo. Chegou inclusive a desenhar com as próprias mãos numerosos animais, peixes e plantas?.

Hoje a distinção entre conhecimento empírico e livresco pode nos parecer óbvia. Mas o critério estava longe de ser aplicado pelos intelectuais da época, que debatiam com idêntico interesse os relatos em primeira pessoa e os comentários feitos a posteriori. Na verdade, o que se verificava era um processo de legitimação recíproca, de simbiose, que tendia a fundir essas duas formas de descrever as singularidades do planeta. A autoridade de um explorador de gabinete era tanto maior quanto mais ele soubesse se manter informado sobre as viagens em curso; e, vice-versa, a credibilidade de um aventureiro dependia não só das coisas inusitadas que descobria no mundo, mas também da sua capacidade de inserir tal experiência num quadro referencial de origem marcadamente letrada e clássica.
9. Massimo Donattini (1980); Silvio A. Bedini (1992); e K Myers (1993, pp. 183-214).

Annals of Museu Paulista. v. 17. n.1. Jan. - June 2009. 
10. Adapto aqui certos jogos de palavras que Rabelais criou parodiando referências etnográficas típicas dos mapas da época. Os Élastipodes estavam provavelmente para os "Antípodas"; os Égipans soavam como a fusão cômica entre egipciens e gitanes ("egípcios" e "ciganos"); os "Etiopálidos", derivação do rabelaisiano Blemmyes (do verbo blêmir, "empalidecer") e da etimologia grega do termo "Etíope" (aithíops, "cabeça negra"), talvez não aludiam a outra raça senão os próprios europeus. No original se lê: "Ils parlaient des Pyramides, du Nil, de Babylone, des Troglodytes, des Élastipodes, des Blemmyes, des Pigmées, des Cannibales, des monts Hyperborées, des Égipans, de tous les diables, et tout par Ouï-dire." Cf. François Rabelais (1973, liv. 5, cap. 30).
Esse compromisso, que dominou o saber geográfico até o século XVIII, foi retratado por François Rabelais na insólita figura de Monsieur Ouï-dire lo senhor Dizer-sim). Com o corpo coberto de orelhas, a boca dotada de sete línguas, cada uma das quais dividida em sete partes - personagem teria o dom de discursar contemporaneamente em diversos idiomas, mas, cego e paralítico, estava condenado a nunca sair do mesmo lugar. A vida inteira de um homem não bastaria para se saber a centésima parte do que ele ensinava. Mesmo assim Rabelais o imaginava cercado de curiosos que, num arco de poucas horas, viravam misteriosamente especialistas em tudo. Começa então a exposição de um conhecimento situado a meio caminho entre o exotismo e a burla, que inclui as Pirâmides, o Nilo, a Babilônia, os montes Hiperbóreos, os Trogloditas, os Pigmeus, os Canibais, os Egiciganos, os Elastípodas, os Etiopálidos ${ }^{10}$.

Qual era o truque de Monsieur Ouï-dire? De onde vinha seu enciclopedismo e sua miraculosa capacidade de síntese? A resposta está num mapa que representava a totalidade do universo e que ele elucidava com aforismas sumários. Voltaremos mais adiante a estes dados, que alternavam o espaço físico ao espaço humano, a este pontilhismo elementar que estava na base da operação cartográfica. Por ora valeria a pena examinar mais de perto quem eram os discípulos do sábio. Rabelais formulou um elenco no qual vemos desfilar, sem qualquer distinção, os nomes de Heródoto, Plinio, Solino, Pomponius Mela, Estrabão, Marco Polo, Jacques Cartier, Pedro Álvares Cabral e o nosso já conhecido Anghiera. Como se vê, a bordoada era transversal: modernos e antigos, vagamundos e eruditos, empíricos e teóricos, todos caíam na armadilha de honrar uma ciência, a cosmografia, cuja regra fundamental era dizer "sim" a tudo.

Confirma-se assim a impressão segundo a qual a viagem dos livros podia, na época, valer tanto quanto a das caravelas. Mas a sátira de Rabelais nos leva a um grau mais profundo de compreensão do problema. Porque a doutrina daqueles homens talvez divergisse no método, mas certamente não divergia no conteúdo. $\bigcirc$ que Rabelais tinha em mira era o modo com o qual o conhecimento geográfico da época se acumulava e se estruturava. Seu alvo era, ao mesmo tempo, o conformismo intelectual dos viajantes e o imobilismo dos cosmógrafos, colocando ênfase na rede de informação que articulava a ambos e legitimava um certo arranjo cognitivo, uma epistémè. Estamos, enfim, diante de um grupo sociologicamente heterogêneo, mas bastante coeso do ponto de vista cultural. Compartilhando os mesmos valores, viajantes e cosmógrafos atuaram juntos na tarefa de inserir as terras recém-descobertas na ordem do mundo conhecido.

Máquinas geográficas

Mas atuaram em nome do quê? Sobretudo, atuaram para quem? $\mathrm{Na}$ verdade, a forma como cada relato de viagem foi codificado numa linguagem 
comum (a dos mapas e dos tratados geográficos) precisa ser interpretada historicamente. Estamos diante de um discurso que, como qualquer outro, veicula valores, explicita matrizes intelectuais e evoca uma determinada unidade entre saber e poder. $\bigcirc$ conhecimento geográfico era, enfim, um fato social complexo. Sua elaboração evidencia diferentes configurações institucionais envolvendo o Estado, a lgreja e o mercado ${ }^{1}$.

Durante os séculos XIV e XV, os circuitos de produção e transmissão de cartas - fossem elas mapas-múndi, topografias ou portolanos - permaneceram relativamente independentes dos centros de poder político. Também é certo que muitas cartas topográficas foram financiadas por senhores e por autoridades comunais, com o fito de sustentar determinadas disputas territoriais ou fundiárias. Mas a atividade cartográfica continuava a ser artesanal e comercial. Em termos práticos, ela não se distinguia de outras manufaturas de luxo, tais como a produção de livros, armaduras, móveis e tecidos finos. Aliás, tudo leva a crer que, no caso das cartas regionais de grande escala, a cartografia fosse uma atividade bem menos especializada que tantas outras. Os artesãos que se dedicavam a ela eram, na sua maior parte, anônimos e limitavam-se a imitar tradições figurativas locais. Mesmo no caso dos artistas mais renomados, a produção de mapas permaneceu, até o século XVI, uma atividade ocasional, extremamente esporádica e numericamente limitada. Os governos não procuraram monopolizá-la nem fizeram dela qualquer uso específico ${ }^{12}$.

Tal autonomia, na verdade, também pode ser constatada no caso da produção cartográfica mais bem remunerada: a dos portolanos. Concebidas como um guia de navegação, estas representações tornaram-se muito apreciadas pelos príncipes, senhores e mercadores. Grande parte das cópias que chegaram até nós escaparam do desgaste pelo uso, pelo sal e pela humidade justamente porque foram feitas com requinte para enriquecer as bibliotecas e os arquivos reais.

Seja como for, a colaboração entre governos e cartógrafos é documentada desde o século XIV. Em 1354, um regulamento catalão estipulava que cada galera devia levar a bordo duas cartas-portolano; ao passo em que um número ainda maior de tais cartas podia ser encontrado nas embarcações genovesas. Mas a forte demanda, com finalidades práticas e estéticas, por este tipo de representação nunca ensejou um esforço monopolista da parte dos governos. Ao contrário, constituiu a base econômica para que a cartografia náutica se tornasse uma atividade comercial autônoma. De fato, os portolanos revelam duas peculiaridades que tendiam a reforçar-se mutuamente: a prática quase irrestrita da cópia e o caráter supranacional do seu circuito de consumo.

Essa difusão, que independe dos poderes institucionais, parte de uma lenta construção coletiva e foi decisiva na gestação da cartografia dos Descobrimentos. Estamos agora em posição de entender o que dava a Ariosto a convicção de ver mais do mundo nos mapas que nas viagens. Consultar tal ferramenta de conhecimento significava apreender um cabedal potencialmente ilimitado de informações consideradas características das diferentes partes do globo. Tomadas de per si, elas não representavam nada além de nomenclaturas,
11. Aqui e nas páginas que seguem, baseio-me sobretudo em Duccio D. Sacchi (1997).

12. Ver P. Harvey, 1987. 
13. "Tereis de informar-nos das ditas ilhas e terra firme que assim descubrirdes e fazer memória de todas as ditas ilhas e da gente que [há] nelas e da qualidade que são para que de tudo nos tragais inteira relação." Instruccion de los Reyes a Colon para el viaje que habia de emprender (14.3.1502). Cf. Juan Pérez de Tudela (1994, p. 1441).

14. Ver José Luis Peset (1989).

15. "Da carta daquela viagem não é possível obtê-la porque o Rei pune com a vida quem as manda para fora". Primera Carta de Angelo Trevisan (21.8.1501). Cf. Juan Pérez de Tudela (1994, p. 1280). contrastes, linhas e pontos desenhados no papel. Mas, interpretadas em conjunto, examinadas no quadro das suas respectivas posições, da sua maior ou menor acessibilidade em relação ao observador, formavam uma totalidade significante cujo valor cognitivo era fácil de assimilar - e por isto mesmo, quando entravam em circulação, não demoravam a conquistar o favor do público. Os mapas, enfim, veiculavam dados extraordinariamente sucintos e simplificados, funcionando de modo análogo aos chamados datagramas, blocos de radicais semânticos que trafegam sob forma condensada nas atuais redes informáticas.

Não por acaso, os venezianos, os ragusanos e, mais tarde, com mais rigor, os portugueses e os castelhanos fracassaram na tentativa de controlar a proliferação da informação geográfica. Em seguida, teremos ocasião de retornar a este ponto. Por ora, seria importante salientar que o estatuto privado e comercial de que gozava o cartógrafo tendia a colocá-lo numa posição privilegiada. $\bigcirc$ mapa era um bem precioso, dotado de forte reconhecimento social: não uma emanação direta do Estado.

Em parte, esta situação mudaria no século XVI. Dos mapas medievais produzidos eventualmente com financiamento oficial, passou-se à elaboração de projetos mais orgânicos, ligados ao aparato militar ou à magistratura civil. A primeira iniciativa nesse sentido remonta às instruções reais dadas a Colombo antes da sua quarta viagem, em 1502. Já aqui podemos verificar o interesse pela precisão topográfica e etnográfica, que se transformaria na principal tônica das futuras Relaciones Geográficas do México e do Peru. O documento é explícito: "aveys de ynformarnos de las dichas yslas e tierra firme que asy descubrierdes e faser memoria de todas las dichas yslas e de la gente que [ay] en ellas e de la calidad que son para que de todo nos traygays entera relaçion"13.

A preocupação em obter informações sobre a América não demoraria a contagiar outras autoridades européias. Basta pensar nas ordens religiosas, em particular os jesuítas no Brasil e os franciscanos no México cujo trabalho de observação sistemática teria, a partir de meados do século XVI, um peso cada vez mais determinante nas representações do novo continente ${ }^{14}$

Porém nada se compara em termos de eficácia, organização e capilaridade à operação efetuada pelas coroas ibéricas. A prática de controle oficial da informação assumiria aqui um alcance sem precedentes. Há evidências recorrentes de que o aparato censório foi empregado para evitar a circulação de dados geográficos estratégicos. Embora a vigilância sobre os escritos de história natural costumasse ser bem menos severa, a razão de Estado muitas vezes prevaleceu sobre a curiosidade do público leitor. Num relatório datado de agosto de 1501, o oratore (embaixador) veneziano em Madrid lamenta a inexistência de mapas com a nova rota dos portugueses para a Índia, declarando: "De carta de quel viazo non e possibele haverle chel Re ha messo pena la vita a chi le da fora" ${ }^{15}$. É interessante lembrar, a propósito, que a publicação das crônicas de Castanheda e João de Barros em Portugal só foi autorizada após a quebra do monopólio sobre as especiarias e a difusão dos relatos de viagem dos jesuítas na França e na ltália. O comércio oriental, de fato, sempre foi cercado de uma aura 
de mistério. Ao longo de todo século XVI, as notícias mais confiáveis sobre a matéria só eram disseminadas através de epístolas reais e relatos de embaixadores - o que acabou por se traduzir num conhecimento meramente factual, fragmentário e vago. Entre 1550 e 1580, período marcado pelo florescimento da cartografia de Ortelius e Mercator, praticamente nada de novo foi publicado sobre as rotas do Oriente (Figura 3). O ponto sensível continuava a ser o celeiro de ervas aromáticas, as Molucas, de cuja localização exała dependia a divisão da América pelo meridiano de Tordesilhas ${ }^{16}$.

Todavia, no campo da informação geográfica, as coroas ibéricas tiveram muito mais sucesso em concentrar e sistematizar que em censurar. Como é sabido, o caráter altamente imprevisível da navegação induziu o aparecimento de organismos estatais destinados a coordenar a aventura no ultramar. Em vista da complexidade burocrática com a qual foram montadas, não seria exagero dizer que estamos diante das primeiras instituições científicas da Europa. A iniciativa
16. Ver Donald F. Lach (1965, p. 226-227); e, também, Kirti N. Chauduri (1985).

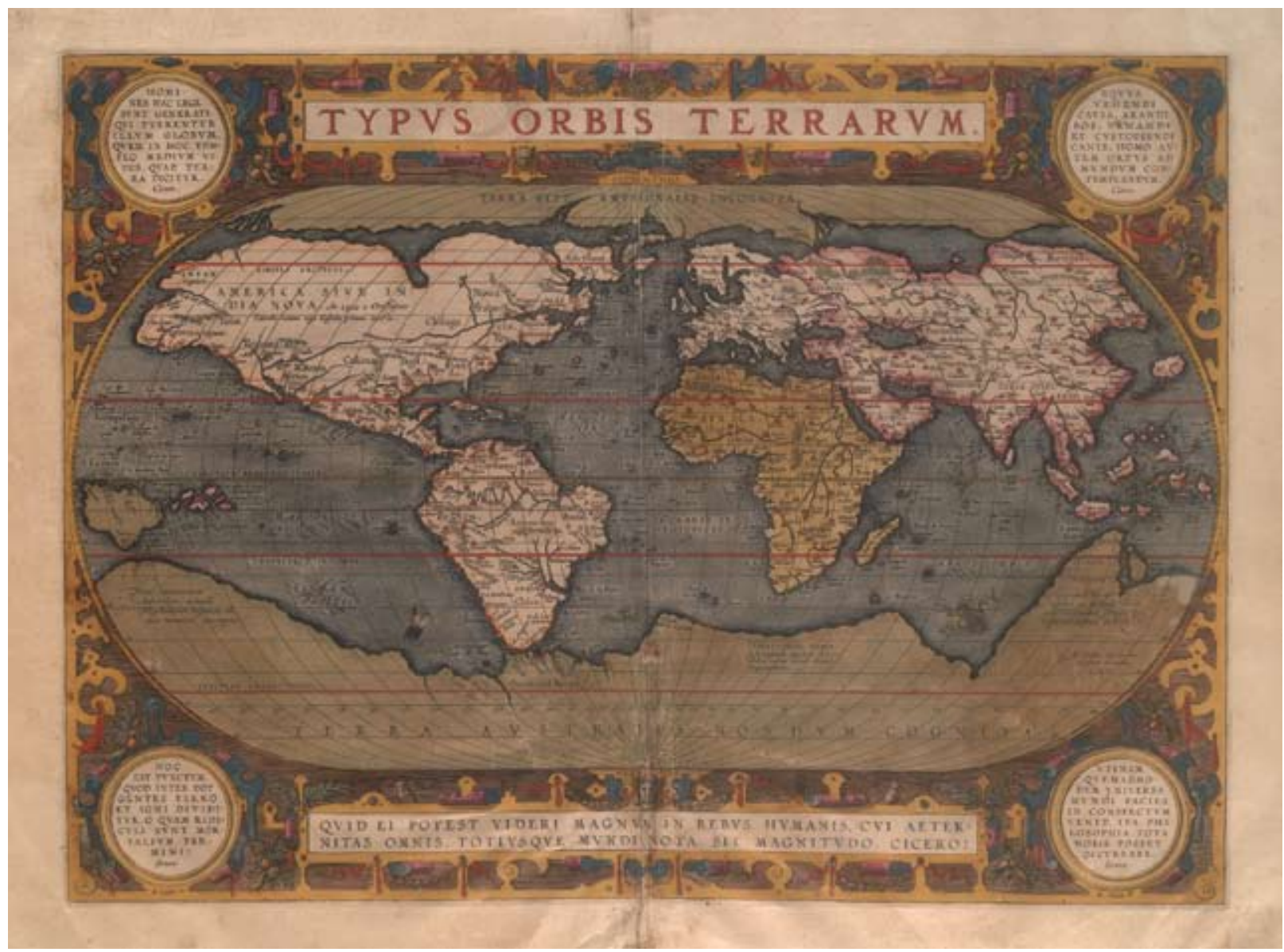

Figura 3 - Typus Orbis Terrarum, 1571. Abraham Ortelius, Theatrum orbis terrarum, Antuérpia, 1587. Fundação Biblioteca Nacional, Rio de Janeiro. 
17. Ver R. Núñez de Las Cuevas (1991); e Juan Pérez de Tudela (1994)

18. Cf. David Turnbull (1996) pp. 7-14.

19. Felipe Gorostiza Arroyo (1997); e novamente Duccio Sacchi (1997). coube a Portugal, ainda nos tempos do príncipe D. Henrique, com a Casa da Mina. Décadas mais tarde, o exemplo seria imitado e superado pelos espanhóis com a célebre Casa de Contratación. Bastaria correr os olhos sobre a lista dos especialistas que ocuparam o cargo de "piloto mayor", todos navegantes exímios, para se ter uma ideia bem precisa da importância histórica da instituição: Americo Vespucci, Juan Díaz de Solís, Sebastião Caboto e Alonso Chaves ${ }^{17}$.

Ambas as Casas foram concebidas para cobrir um vasto espectro de funções técnicas e políticas. Era a elas que cabia regular os ritmos do tráfico comercial entre a metrópole e as conquistas. Deviam ainda conceder licença aos pilotos, designar tripulantes, especificar rotas e missões. Por fim, quando do retorno de cada nova armada, deviam recolher e supervisionar os dados cartográficos disponíveis sobre as terras recém-descobertas. Este último propósito assumiu expressão concreta com o estabelecimento do "Padrão Real": tratava-se de um mapa único no qual estariam contidos os resultados de todas expedições até então empreendidas. Nas palavras do decreto que o instituiu em Castela, é "por el que todos los Pilotos se hayan de regir y gobernar" 18 .

Com o avanço da conquista da América, Castela se dera conta da necessidade de concentrar o conhecimento oficial sobre o continente nos moldes da Casa de Contratación. Data de 1528 a primeira requisição oficial de informações, acerca da Nova Espanha, que no início tinham caráter estritamente administrativo, destinando-se a coletar dados para garantir a defesa, a administração e a exploração econômica. Anos mais tarde, criou-se um cargo que permaneceu ativo até fins do período colonial, o "cronista-cosmógrafo". E fácil perceber que suas funções coincidem com a do "piloto mayor", exceto por um particular: ele estendia sua competência não apenas sobre as rotas marítimas mas sobre os domínios espanhóis como um todo.

De acordo com a ordenança de 1571, a tarefa do cronista-cosmógrafo compreendia dois campos de ação. O primeiro era traduzir em mapa as descrições geográficas provenientes do Novo Mundo. Era também a ele que cabia nomear, nas principais cidades, funcionários encarregados de executar o cálculo das longitudes com base nos eclipses lunares. Enfim, depois de sistematizados, os dados deviam ser inseridos no Libro de las Descripciones. A segunda tarefa dizia respeito à crônica propriamente dita - isto é, fazer a compilação de uma história geral das Índias, realizada com base nas relações que chegassem ao Conselho. A ordenança ainda especificava que o cronista devia organizar uma história natural relativa às "yerbas, plantas, animales, aves y pescados" das terras indianas. Os resultados obtidos seriam abertos à consulta apenas para pessoas autorizadas. Implícita em toda a operação estava a ideia de que o caráter caleidoscópico dos questionários oficiais (a paisagem, a natureza, os povos) pudesse ser definido com a mesma objetividade com a qual eram conhecidas as posições de uma itha ou a configuração de uma costa. O resultado seria, ao menos era o que se esperava, um conjunto de dados confiáveis e passíveis de confronto com grande utilidade científica e operativa ${ }^{19}$.

Vem natural pensar no cego, paralítico e onisciente Ouï-dire, a tudo 
escutando com seu corpo coberto de orelhas. O caso é que o Estado já não mais agia como simples arquivo e registro das novas cartas, mas sim ditava as regras para a sua elaboração. Era também o Estado a dar sentido às diferentes imagens sobre as conquistas ultramarinas a partir de um modelo único - o Padrón e, depois de 1571, o Libro. Se o primeiro devia fazer justiça a todas as cartas náuticas que nele confluíam, o segundo devia ser a súmula das relações sobre a América. Ambos foram concebidos como representações certas e secretas do mundo, representações para o governo e nas mãos do governo.

No entanto, nada disso exclui que elas acabassem por servir, direta ou indiretamente, a outros interesses. Antes de mais nada, valeria a pena sublinhar o significado comercial inerente a toda a operação. Embora dependente do poder público, esse tipo de cartografia tinha em vista a elaboração de mapas confiáveis, além da formação de pilotos e guias competentes. Seus beneficiários mais imediatos foram, portanto, os próprios mercadores que tiveram reduzidos os riscos de perda da carga ao longo das travessias marítimas e terrestres.

É interessante ressaltar ainda a afinidade que, neste particular, as elites demonstraram com o governo metropolitano. Não eram raros os nobres da terra que recolhiam por conta própria as memórias e conhecenças da população local. Ainda hoje, dispomos de histórias gerais desses cronistas "espontâneos", compartilhando a linguagem e os valores (embora não a abrangência) do saber oficial. Eis o que fez em 1584 o criollo mexicano Baltasar Obregon, cujos manuscritos foram enviados a Madrid com vistas à obtenção de uma mercê real ${ }^{20}$. Por esta mesma época, o cartógrafo português Luís Teixeira produziu seu gracioso Roteiro de Todos os Sinais, incluindo doze plantas, descrições do litoral e um grande mapa da América Portuguesa. A obra, que inventariava a experiência dos pilotos engajados na carreira do Brasil, segue de perto a sintaxe dos mapas oficiais e quase poderia ser definida como um Padrão Real em miniatura. É interessante notar, de resto, que, realizado já sob domínio filipino, o Roteiro foi financiado por uma rica família de negociantes sem qualquer participação do governo ${ }^{21}$. Casos como estes sugerem que, entre o olhar atento do Conselho de Indias e o interesse de potentados do mundo atlântico, verifica-se um quadro de permeabilidades recíprocas - não de imposição nem menos ainda de segredo.

Enquanto essa transição se consumava, um lento e inexorável processo de corrosão do segredo também tomava lugar. Como não poderia deixar de ser, havia a pressão exercida por espiões, agentes comerciais, náufragos e contrabandistas que acabavam por expor inumeráveis dados relativos a rotas marítimas, produção de especiarias, condições políticas da Ásia e assim por diante. Mas havia também contingências que forçavam o próprio governo a fazer o mesmo. Como veremos a seguir, a propaganda oficial muitas vezes tornou a divulgação do conhecimento tão ou mais premente que a necessidade de ocultá-lo.
20. Ver Baltasar Obregon (1997).

21. Ver Luís Teixeira (1988). 
22. Jaime Cortesão (1997).

23. Ver Francisco Contente Domingues (1998, p. 65).

24. Década I, liv. V., cap. IV. Cf. K. Chaudhuri (1998, p 514-515).

25. Jacob Burckhardt (1991, p. 124).
O vôo da fama

Informação é um bem volátil. Boa parte daquilo que era escondido pelas instituições oficiais acabava por circular no ambiente cortesão; e o que circulava nas cortes não demorava a ser apropriado também pelos meios de difusão impressa do conhecimento geográfico. $\bigcirc$ leitor atento há de ter notado que tangencio aqui uma das teses mais debatidas dos Descobrimentos. $\bigcirc$ historiador português Jaime Cortesão sugeriu que a cartografia e a arte da navegação constituíam o saber tecnológico mais cobiçado na época. Com base em numerosos documentos oficiais, ele sustentou que os governos ibéricos exerceram um controle ferrenho sobre as notícias do ultramar ${ }^{22}$.

Que houve leis restritivas contra o movimento de cartógrafos, pilotos e estrangeiros suspeitos é fora de questão. Assim como é indubitável que, ao menos nas primeiras décadas da conquista, o Estado foi o principal pólo fomentador e arregimentador de dados geográficos. Mas seria exagero falar em "política do segredo", como se os governantes seguissem uma linha de ação consciente e unívoca. A historiografia recente vem demonstrando, ao contrário, um acúmulo de posturas contraditórias somadas à evidente incapacidade de conter o voo da fama ${ }^{23}$.

A experiência do reinado de D. João ll é, nesse sentido, emblemática. Em 1481, as cortes aprovaram uma provisão solicitando à coroa que negasse a autorização para que cidadãos de Gênova e Florença se fixassem no reino. Contudo, com a expulsão dos judeus (1497), o rei se viu obrigado a contar com o financiamento italiano para a realização de seu intento marítimo. Merece aqui destaque a casa florentina dos Marchioni, que custeou uma das naus de Cabral, além de outras expedições no Índico entre 1507 e 1514. O chefe da firma em Lisboa, Bartolomeu Marchioni, chegou inclusive a ser homenageado por João de Barros²4.

Aliás, em 1491, outro italiano já tinha exortado D. João a cuidar da sua glória enquanto vivo, enviando a Florença todo o material relativo às navegações portuguesas na África, a fim de que o mesmo fosse dignamente "estilizado" em latim. Caso contrário, prosseguia a advertência, o monarca correria o risco ser esquecido no "amontoado da fragilidade humana". Palavras fortes, que beiravam a petulância. Mas ninguém pode negar que o autor delas era um perito em notoriedade pública: estamos falando de Angelo Poliziano, poeta dos mais eminentes na corte de Lorenzo, o Magnífico ${ }^{25}$.

Infelizmente não sabemos se D. João mostrou-se sensível ao pleito. certo é que seu sucessor, D. Manuel, encomendou uma Bíblia ricamente iluminada na oficina do miniaturista Gabriello dei Vanti degli Attavanti, sempre em Florença. No frontispício do primeiro volume, vemos a imagem de um frade entretido em seus estudos. Além de livros e figuras sacras, o escritório contém uma pequena coleção de objetos científicos (uma esfera armilar, um relógio mecânico, um astrolábio) e, em matizes de azul, um planistério em projeção cônica do tipo 
Martellus que representava a Ásia e parte da África utilizando numerosas referências náuticas de origem portuguesa ${ }^{26}$.

Anos mais tarde, por ocasião das núpcias reais entre $\mathrm{D}$. João III e Catarina de Áustria (1525), a coroa portuguesa mandou fazer em Bruxelas uma série de tapeçarias intituladas As Esferas. A ideia era celebrar a união entre os Avis e os Habsburgo ressaltando a grandeza de seus vastíssimos impérios. Feita a partir de esboços atribuídos ao pintor flamengo Bernard van Orley, a série visava ratificar a legitimidade e a autoridade de ambas monarquias. Seu ponto culminante é a peça que representa o globo terrestre ladeado pela figura dos noivos vestidos como Júpiter e Juno (Figura 4). D. João, envolto num magnífico manto vermelho e

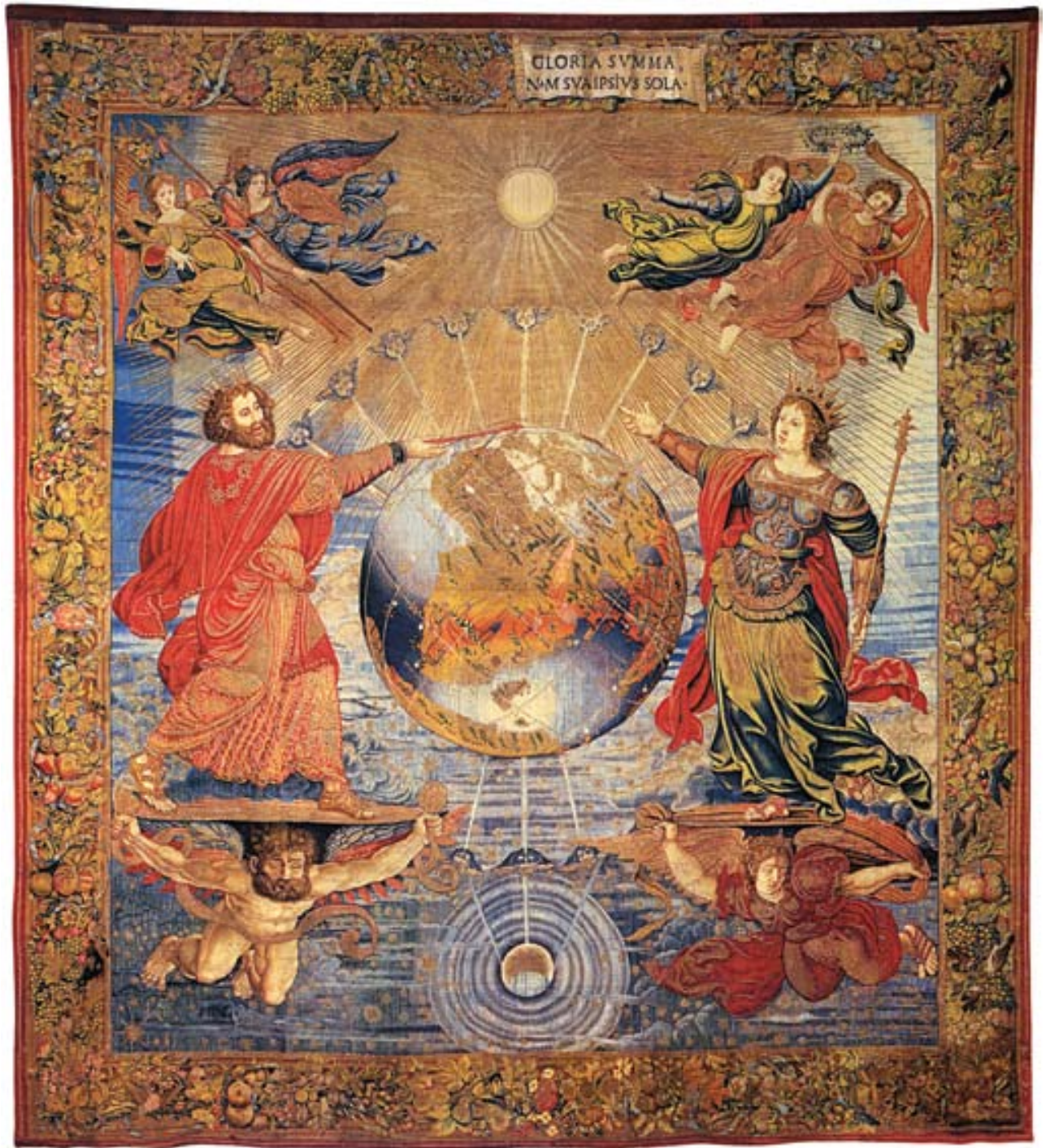

Figura 4. Bernard van Orley, As Esferas (detalhe do planeta amparado por Júpiter e Juno), ca. 1530, tapeçaria com tamanho original, 344 X 314 cm, Museo del Escorial, Madrid. Fonte: Os construtores..., 1998.
26. Como consta da Bíblia dos Jerônimos (1495) e reproduzido por F. F. Paulino (1994, pp. 138-139). 
27. Trata-se de uma extensão hipotética da Terra do Fogo. Ver Jerry Brotton (1997, pp. 17-22).

28. Hoje na Bibliothéque Nationale de Paris, cf. Armando Cortesão (1935)

29. Na Biblioteca Nazionale di Firenze. As cartas "Castiglioni" (r. 180) e "Salviatti" são atualmente atribuídas a Diego Ribero e a Nuño Garcia de Toreno. dourado, pousa o cetro sobre Lisboa como para assinalar o ponto de partida de domínios coloniais que se estendiam por meio mundo. $\bigcirc$ mapa registra com impressionante nível de detalhamento a Guiné, a Angola, o cabo da Boa Esperança, o reino do Monomotapa, o Mar Vermelho, o Golfo Pérsico e a Índia. Na extremidade da representação, vemos ainda um trecho da Terra Australis, o continente meridional imaginário "descoberto" apenas cinco anos antes por Magalhães ${ }^{27}$.

Esses vestígios iconográficos são eloquentes. Surpreende que pintores e miniaturistas tivessem conhecimento tão profundo de uma arte especializada como a cartografia. Significativo é também o fato de que portugueses, italianos e flamengos reconhecessem uma matriz geográfica única, representando o mundo segundo o mesmo traçado. Vê-se que a marca ptolomaica da representação geométrica do espaço já campeava a elite culta como um idioma visual comum. Mas estamos, acima de tudo diante de uma flagrante contradição com a ordem real de limitar o fluxo da informação geográfica. É evidente que aqueles artistas foram instruídos por agentes da própria coroa portuguesa a incluir em suas obras mapas da melhor qualidade. Tudo leva a crer que o pequeno mundo azul de Vanti degli Attavanti não divergia tanto do outro, oficial e muito maior, que em Lisboa servia para instruir as navegações no ultramar. Raciocínio análogo vale para van Orley que presumivelmente não teve dificuldade em reconstituir a misteriosa rota para Calecute frequentando o mercado de estampas impressas em Bruxelas. A propósito, é interessante notar que a mesma configuração adotada pelo pintor flamengo para representar o sudeste africano, já incluindo as ilhas de Madagascar e Zanzibar, reapareceu poucos anos mais tarde, num mapa publicado em Paris, a Nova et Integra Universi Orbis, de Oronce Finé (1531).

Obviamente a necessidade dos reis de imortalizar os próprios feitos era comum em toda Europa. Mas no caso das coroas ibéricas a tarefa possuía uma motivação suplementar. A auto-promoção tinha um peso estratégico decisivo no sentido de legitimar a posse sobre os colossais territórios ultramarinos. As duas representações que examinamos antes sugerem que houve, senão uma "política", ao menos uma prática consciente de publicidade. Assim, embora o Padrão Real tivesse um caráter reservado, seu traçado chegou até nós através de cópias feitas em circunstâncias especiais. Lopo Homem preparou, em 1519, uma reprodução magnificamente decorada do padrão português. Dividida em diversas folhas e com inscrições traduzidas em latim como nos futuros atlas, a obra era uma prova de amizade enviada por D. Manuel a Francisco ${ }^{28}$. Carlos V, por ocasião das bodas imperiais em 1526, também presenteou duas cópias do cobiçado padrão espanhol ao embaixador Baltasar Castiglioni e ao cardeal Salviatti29.

Reproduções manuscritas como estas seriam consultadas e copiadas pelos humanistas, servindo de base a grande parte do acervo que fez a história da cartografia impressa no século XVI. As imagens que então começavam a ser difundidas ao público leitor no restante da Europa refletiam um patrimônio cartográfico, vasto e homogêneo, que nasceu - ou ao menos foi fecundado - nos arquivos ditos "secretos" da burocracia ibérica. 
31. Mesmo os melhores estudos sobre a história do saber geográfico traem uma atenção obsessiva às ditas "esco-

Não surpreende que os historiadores da ciência tenham dado tanta ênfase à chamada "revolução geográfica" do Renascimento. Ao longo de anos, tais intérpretes tenderam a delinear certos focos em que produção intelectual teria sido especialmente ativa. Sua análise recaía quase exclusivamente sobre um número limitado de teóricos que, nos moldes da cartografia estatal, se concentravam em explorar os limites de um saber ainda em formação. Era como se a crescente acuidade de mapas e compêndios geográficos procedesse autonomamente, como se brotasse do dinamismo interno da própria disciplina sem a intervenção de fatores culturais exógenos.

Ocorre que tal aprimoramento, a substituição "espontânea" do erro pelo acerto, nem sempre aconteceu. Aliás não foram raros os casos de reedições que simplificavam a carta matriz, revelando uma toponímia mais limitada, menos linhas de rumo e menos precisão no traçado dos continentes. Entre outros exemplos, temos a Carta Marina, de Waldseemüller (1516), que, nove anos mais tarde e pelas mãos de Fries-Grüninger, reapareceu numa versão que eliminava boa parte de seu rebuscamento original, especialmente na figuração da Europa. É curioso notar que os caracteres góticos presente nas cópias conhecidas do mesmo mapa foram aqui substituídas por caracteres romanos e, também, que os textos geralmente escritos num dialeto alsaciano do alto alemão - foram vertidos para o latim. Tais mudanças indicam uma preocupação com a legibilidade da obra e uma possível inserção em áreas de fala não germânica. De fato, em suas sucessivas edições, a Carta Marina de Fries-Grüninger já não era mais um produto de erudição cosmográfica. Sua pretensão era outra: a popularização e o comércio, destinando-se ao grande público da feira anual de Strassburgo ${ }^{30}$.

O pior é que a tese do foco de saber acabava evocando involuntariamente as "escolas" geográficas, cuja imagem enfeitiçou autores adeptos do romantismo nacionalista. $O$ mito da Sagres de D. Henrique, tantas vezes desmascarado, continua a se reproduzir em outras paragens. Assim como ainda corremos, provavelmente, o risco de ver ressurgir as especulações em torno de episódios de corte, francamente auto-centrados, como os primeiros debates florentinos sobre Ptolomeu no convento degli Angeli (entre 1410 e 1440); ou, ainda, sobre a importância da linhagem dos "papas geógrafos" (Alexandre V, Paulo II, Sixło IV e Pio II) que, com seu fascínio por terras longínquas, teriam antecipado o ecumenismo de Trento ${ }^{31}$.

Na verdade, a chave para compreender a geografia renascentista não está na intuição, no gênio dos humanistas. Está, sim, na irradiação do saber e na tensão entre circuitos (de trocas intelectuais) ligados como numa teia que se espalhava por todo o continente europeu. Esta é a estrutura vasta e assimétrica, 
32. A já citada Colección Documental del Descubrimien to de Juan Pérez de Tudela nos oferece mais de uma dezena de registros desta natureza. que abrangia conhecimentos empíricos e livrescos, espionagem e propaganda, aparatos estatais e simples curiosos, a explicar o sucesso dos planisférios. Também é ela a formar a audiência transnacional, cuja demanda daria origem, na segunda metade do século XVI, aos teatra mundi e às grandes coleções de relatos de viagens, de Ramusio a Theodor de Bry (Figura 5). A inovação do pensamento geográfico, que inegavelmente se consumou na época, teria sido impossível se não fosse pela existência de um organismo coletivo que redesenhou a face da Terra basicamente por ouvir-dizer.

Passemos, agora, a examinar o fenômeno de outra perspectiva. À semelhança de qualquer peça rendada, um tapete por exemplo, cujos fios se cruzam, enlaçam-se e se separam, o ouvir-dizer também era uma trama que se prolongava no espaço, intercalando zonas de adensamento e de dispersão. Vimos como os dados obtidos no ultramar eram coletados e reelaborados nos gabinetes de eruditos ou de organismos institucionais. Vimos, ainda, como o resultado desta operação, que assumia quase sempre a forma de um mapa, voltava a desvincular-se do âmbito da autoridade, afastando-se de suas formas de controle, para cair no domínio público. Todos elementos que compunham a estrutura, não custa insistir, estavam conectados entre si e tendiam a se influenciar reciprocamente.

Ora, se estamos diante de canais de transmissão cultural, caberia ainda que de maneira provisória e parcial - reconstituir seu percurso. Qual era o fluxo do saber geográfico no período dos Descobrimentos?

Nossa rede tem naturalmente início nos portos atlânticos de Cádiz e Lisboa, sem esquecer o porto mediterrâneo de Sevilha, para onde convergia a quase totalidade dos viajantes que andavam por terras novas. Ali os relatos passavam a um diversificado grupo de informantes de segunda-mão, entre patrícios e forasteiros. A inteirar-se da coisa, além dos oficiais das respectivas "casas de contratação", havia marinheiros, soldados, mascates, mercantes de grosso cabedal e emissários de cortes estrangeiras. Como é fácil supor, foram apenas os últimos a deixar traços documentais sobre os murmúrios que circulavam neste meio. Trata-se, em sua maioria, de notas fragmentárias, sucintas e marginais, mas que nos dão acesso à curiosidade popular durante a partida e a chegada de certas expedições ${ }^{32}$.

Ainda em estado bruto, desordenado e desprovido de qualquer mediação culta, esse "datagrama" infiltrava-se nos grandes circuitos comerciais da época. Através de embarcações patrocinadas pela liga hanseática, partiam da Península lbérica com destino ao Báltico e desembarcavam, por exemplo, no remoto porto de Gdanski. Tal fluxo quiçá justifique o aparecimento de figuras como - humanista Jan Dantiscus, que também atuou como diplomata na Espanha entre 1524 e 1529. Tendo conhecido pessoalmente e trocado cartas com Hernán Cortez, Dantiscus redigiu três comentários sobre as terras recém-descobertas, hoje perdidos, e deixou aos herdeiros uma biblioteca que incluía mapas e globos indicando a rota para as Índias Ocidentais. Figura análoga foi o magnata Krzysztof 
Szydlowiecki, que, em 1529, fascinado pelo exotismo americano, escreveu a Dantiscus pedindo para ser presenteado com nada mais nada menos que um índio vivo! 33

Outras embarcações, transportando o mesmo conjunto de dados, rumavam pelo Mediterrâneo. Na Itália, assim como acontecia na Polônia, este datagrama de segunda-mão e de baixíssima qualidade técnica não demoraria a pousar na mesa dos eruditos. Temos assim o caso do veneziano Alessandro Zorzi, meticuloso colecionador de relatos de viagem que, entre 1470 e 1535, compilou cinco volumes, em boa parte ainda inéditos, com fragmentos de textos impressos e manuscritos, apontamentos teóricos e esboços cartográficos. Abrangendo a Ásia, o Oriente Médio, a África e o Novo Mundo, tal obra faz dele um dos intérpretes mais originais (e menos conhecidos) dos Descobrimentos ${ }^{34}$.

Aliás, na trama que estamos investigando, a coletânea Zorzi ocupa uma posição de singular importância. Colagem de textos alheios, maço de anotações marginais e rascunhos de mapas nunca realizados, este teatrum mundi embrionário retrata o estágio preliminar do processo de elaboração da informação geográfica. Vemos confluir ali os ecos confusos e multifacetados que chegavam do ultramar, bem como a especulação de outros eruditos sobre a conquista e uma boa dose de material de propaganda. Mas a coletânea ficou a meio caminho, e é isto que a torna tão interessante, entre o simples acúmulo de dados e a síntese letrada da cosmografia. Simultaneamente, um número indeterminado de editores também tratava de enriquecer o datagrama não-oficial com as fontes oficiais que começavam a surgir no mercado. Menos ambiciosos e mais sintonizados com o gosto popular, tais indivíduos criaram um acervo de panfletos, opúsculos e avisos que, a partir de sedes em cidades como Roma, Florença e Veneza, propagou-se com grande desenvoltura por meio da produção de impressos sediada em cidades como Roma, Florença e Veneza ${ }^{35}$.

Enquanto se desenvolvia este circuito, a trama do ouvir-dizer era enriquecida por uma fonte alternativa que não pode ser negligenciada. Dispondo de um recurso com o qual os humanistas não podiam contar - o poder institucional -, a coroa francesa estabeleceu sua própria máquina de conhecimento. Desde os tempos de Francisco l, começara a tomar forma, no porto de Dieppe, um núcleo que reunia os dados de origem portuguesa e espanhola à experiência dos contrabandistas de pau-brasil36. Esta oficina cartográfica (muitos a chamam "escola") assinala uma convergência entre interesses de Estado e pirataria, cuja história ainda merece ser melhor investigada. A instituição gozou de considerável prestígio entre os estudiosos, a ponto de influenciar o próprio Mercator. Seu período áureo, entre 1541 e 1553, coincide com os esplêndidos planisférios de Pierre Desceliers que, na cartografia do Renascimento, ocupam lugar de destaque pela riquíssima ornamentação e pelo conhecimento de zonas ainda pouco exploradas como a costa do Peru, a Polinésia e a misteriosa Terra Australis ${ }^{37}$.

Inglaterra e Holanda foram outros países a manter uma relação de
33. Ver Jamusz Tazbir (1968).

34. A primeira coletânea composta de um volume in titulado Successo della Prima Navicatio di Colu[m]bo, encontra-se hoje na Biblioteca Comunale di Ferrara (Mss. cl. II, 10); a segunda, sem título e composta de quatro volumes assinalados como Warthem[a], Alberico, Ximlejvar e Conti, pertencem à Biblioteca Nazionale Centrale di Firenze - Banco Rari, 233-6.

35. Ver Massimo Donattini (1992).

36. Sobre as atividades econômicas do porto de Dieppe e seus reflexos na cartografia, ver Michel Mollat (1952, p. 250,256 e $350-353$ ).

37. Cf. Eric Whitehouse (19771978); e Isa Adonias (1963, p. 105-106). 
38. Para o caso inglês, é im prescindível a obra de Colin Steele (1975); v. também de Marie-Madelaine Martinet (1987); e a de Lesley B. Cormack (1997).

39. Ver Kees Zandvliet (1998).

40. Pius Malekandthil (1999); e Kaspar Vogel (1990). curiosidade indireta para com o processo de exploração marítima. Envolvidos em disputas internas de poder, ambos levariam mais tempo para desenvolver suas potencialidades expansionistas. Porém, na segunda metade do Quinhentos, o despertar do poderio naval britânico protagonizado por aventureiros como Walter Raleigh e Francis Drake foi seguido por um autêntico furor geográfico. Nesse contexto, surgiram obras como o manual de navegação Monarquia Marítima, de John Dee e, mais tarde, a famosa coleção de relatos de viagem de Hakluyt, cujas reedições no século XVII suplantariam o sucesso de Ramusio ${ }^{38}$. Do outro lado da Mancha, em Amsterdã, a crescente pressão dos capitais flamengos, visando a interesses situados fora da Europa, patrocinaria uma produção cartográfica extremamente vibrante. Tinha então início a era das cartas impressas de grande dimensão e de excelente acabamento técnico, que serviam tanto ao estudo dos eruditos quanto à decoração de interiores, enfeitando, como indicam as pinturas da época, o ambiente doméstico da burguesia local ${ }^{39}$.

Visto que é de uma rede que falamos, nossa análise não pode estar completa sem examinar como suas linhas de força atuavam sobre o ponto de partida da estrutura. Que papel o ouvir-dizer teve na Península Ibérica? Vimos antes que, ao longo de toda a primeira metade do século XVI, nenhuma crônica oficial relativa aos Descobrimentos saiu na imprensa portuguesa. Mas a censura não impediu aos humanistas locais de consultar a literatura sobre o mundo extraeuropeu publicada por autores estrangeiros, sobretudo italianos e alemães. Assim como não impediu, em 1502, que um certo Valentim Fernandes, originário da Moravia, fosse responsável pela primeira edição portuguesa de Marco Polo e de outros viajantes italianos no Oriente. Um ano mais tarde, Fernandes recebeu cargos oficiais ligados ao ultramar e serviu de ponte nas negociações entre D. Manuel e o mercador Lukas Rem, negociações essas que garantiram a participação do capital alemão no comércio com a Índia. Aliás, demonstrando que o ouvir-dizer era uma teia de mão dupla, o mesmo Fernandes enviou relatos de viagem a Konrad Peutinger, humanista aparentado à família de banqueiros Welser e amigo do imperador Maximiliano I. O material, incluindo relatos sobre a África e a Ásia, foi publicado na Alemanha em 1508 sob o título De Insulis et Peregrinationibus Lusitanorum ${ }^{40}$.

É claro que situações análogas também aconteceram na Espanha, onde - declínio do controle estatal sobre a cartografia e a crescente vulgarização do saber geográfico parecem unidos por um nó comum. Enquanto a cultura do impresso conquistava a Europa, as tentativas de regulamentar a Casa de Contratación se sucediam com frustrante pontualidade. Era, de resto, um traço característico da administração absolutista: traindo a própria incerteza, a Coroa tendia a sobrepor funções e cargos e perdia-se em procedimentos redundantes. São ainda bastante documentados os casos de abuso de autoridade por parte dos pilotos mayores, falta de preparação dos navegantes, falhas na compilação do Padrón Real. Enfim, no último quartel do século XVI, com a fuga de informação 
e o roubo de documentos, a aura de prestígio que cercava a instituição começaria

a ceder até entrar em colapso, definitivamente, com o incêndio de $1604^{41}$.

Considerações finais

Ao privilegiar o senso de observação e a curiosidade, a cultura do Renascimento foi um fator determinante na criação do viajante moderno. Se antes, no tempo do viator medieval, a experiência de pôr-se a caminho, de partir em busca de outras terras subordinava-se a uma motivação mística, agora a mesma experiência passou a conotar uma ocasião de aprimoramento intelectual. Mas quando, graças à navegação, o sonho de visitar os confins da terra tornou-se realidade, foram poucos os humanistas a se entregarem à aventura. Em plena era dos Descobrimentos, a maioria dos homens letrados preferia viver a excursão segura, inerte e enciclopédica da cartografia. Tal atitude não negava o valor cognitivo do viajar. Ao contrário, entre viajantes autênticos e imaginários estabeleceu-se um mecanismo de legitimação recíproca. Empirismo e erudição passaram, assim, a coexistir em estado de equilíbrio forçado, sujeitando o conhecimento ao paralisante conformismo da cosmografia.

Outra importante peculiaridade do período foi a transformação do viajar - vale dizer, viajar fora da Europa - em foco de vigilância estratégica. Os Descobrimentos estavam associados a interesses políticos e econômicos que colocaram o saber geográfico no centro do conflito entre as Coroas ibéricas e outras potências emergentes. Tal contexto implicou no estabelecimento das "casas de contratação", autênticas instituições científicas destinadas a exercer um controle sem precedentes sobre os relatos de viagem. Entre suas múltiplas incumbências, destacava-se a compilação do Padrão Real, uma representação certa e secreta do mundo, na qual convergia o resultado de todas as expedições até então realizadas.

Mas o segredo oficial foi sujeito a um contínuo processo de corrosão. A necessidade de ratificar a posse sobre os novos territórios coloniais tornava a publicidade tão importante quanto o silêncio. Ambas as Coroas passaram a veicular, assim, informações geográficas por meio de aparatos ornamentais, como tapeçarias e miniaturas, ou diretamente, através de cópias reduzidas do Padrão Real, que eram presenteadas a figuras notáveis das cortes rivais. Este material de propaganda não demoraria a ser captado nos ambientes eruditos e integrado ao corpus da cosmografia.

Na historiografia, a derivação do saber entre o Estado e os humanistas serviu para alimentar a tese das "escolas" cartográficas. A progressiva acuidade dos mapas, segundo ela, emanaria de um núcleo de trocas neutras, lineares, transparentes: de um lado, o acesso a dados mais objetivos; e, de outro, a capacidade de síntese de espíritos cultos especialmente dotados. Na verdade, a 
nova configuração do globo que surgiu nos mapas do século XVI refletia um quadro cultural muito mais complexo. A experiência dos viajantes, codificada em enunciados esquemáticos (datagrama), passa a trafegar numa extensa e variada rede de informantes de segunda-mão. Trata-se de um organismo coletivo, marcado por contaminações recíprocas e pela coexistência entre circuitos definidos pelo controle estatal e pelo tráfico de influência, mas também pela espionagem, pelo contrabando e pela mera curiosidade intelectual. Ora estreitando-se nos pontos de estrangulamento do saber oficial, ora alargando-se, com a produção de textos e figuras impressas, em passagens mais dinâmicas, mais incertas, esta trama se ramificava por toda Europa.

Moldado nos portos do trato atlântico, o datagrama dos Descobrimentos era transmitido através da diplomacia e dos canais comerciais mediterrânico e hanseático, indo assim ecoar no âmbito de uma audiência transnacional. Esta informação rudimentar e fragmentária, que aludia indistintamente a localidades na Ásia, África e América, seria sistematizada graças ao trabalho de uma miríade (nem sempre culta) de estudiosos. Enfim, adaptada pela imprensa a um contexto de vulgarização, compendiada e digerida em livros, separatas, mapas avulsos e similares, a nova geografia regressava ao ponto de partida. Não é a primeira vez - nem será a última - que a vontade de saber subverte um poder fiscalizador forte e expõe sua natureza irremediavelmente porosa e frágil.

O aparato burocrático e os interesses de Estado cumpriram, não resta dúvida, um papel importante, mas foram as redes não-oficiais de informação o verdadeiro motor de transformação da geografia renascentista. Em última análise, foram elas, as redes, a permitir que a nação cautelosa e sedentária dos letrados, gente como Ariosto, embarcasse em seus mapas e desse a volta ao mundo... por ouvir-dizer.

\section{REFERÊNCIAS}

ADONIAS, Isa. A Cartografia da Região Amazônica, 1. Rio de Janeiro: Instituto Nacional de Pesquisas da Amazônia, 1963.

ARIOSTO, Ludovico, Orlando furioso. Torino: Einaudi, 1966 (na versão eletrônica: Letteratura Italiana Zanichelli, v. 1, p. 323-349; e v. 2, p. 258-280).

ARIOSTO, Ludovico. Opere minori. Milano-Napoli, Ricciardi, 1954 (na versão eletrônica: Letteratura Italiana Zanichelli).

ARROYO, Felipe Gorostiza. Relaciones geograficas. In: WERNER, Michael (Org.). Encyclopedia of Mexico. Chicago: Fitzroy Dearborn, 1997.

BÍBLIA dos Jerônimos (1495). Lisboa: Arquivos Nacionais da Torre do Tombo, Casa-Forte, 1.

BEDINI Silvio A. (Org.). The Christopher Columbus Encyclopedia. New York: Macmillan, 1992. 
BROC, Numa. La Geographie de la Renaissance (1420-1620). Paris: Comité des travaux historiques et scientifiques, 1986.

BROTTON, Jerry. Trading Territories: Mapping the Early Modern World. London: Reaktion, 1997.

BRUMAN, Henry. The Schaffhausen Carta Marina of 1531. Imago Mundi, London, v. 41, 1989, p. 124-132.

BURCKHARDT, Jacob. A Cultura do Renascimento na Itália. Um Ensaio. Trad. Sérgio Tellaroli. São Paulo: Companhia das Letras, 1991.

CHAUDURI, Kirti N. Trade and Civilisation in the Indian Ocean: an Economic History from the Rise of Islam to 1750. Cambridge: Cambridge University Press, 1985.

CHAUDHURI, Kirti. A recepção européia da expansão. In: BETHENCOURT, Francisco; CHAUDURI, Kirti N. (Org.). História da expansão portuguesa, 1. Lisboa: Círculo de Leitores, 1998. p.512-511.

CORMACK, Lesley B. "Good fences make good neighbors": Geography as Self-definition in Early Modern England. In: DEAR, Peter (Org.). The Scientific Enterprise in Early Modern Europe. Chicago: University of Chicago Press, 1997, p. 64-85a.

CORTESÃO, Armando. Cartografia e cartógrafos portugueses dos séculos XV-XVI, 1. Lisboa: Seara Nova, 1935.

CORTESÃO, Jaime. A política do sigilo nos descobrimentos. In: Obras Completas, 20. Lisboa: Imprensa Nacional, 1997.

CUEVAS, R. Núñez de Las. Historia de la cartografía española. In: La Cartografia de la Península Ibèrica i la seva extensió al Continent Americà. Barcelona: Institut Cartogràfic de Catalunya, 1991. p. 153-223.

DOMINGUES, Francisco Contente. Da exploração do Atlântico à demanda do Oriente. In: BETHENCOURT, Francisco; CHAUDHURI, Kirti N. (Org.). História da expansão portuguesa. Lisboa: Círculo de Leitores, 1998. p.62-87.

DONATTINI, Massimo. Giovanni Battista Ramusio e le sue Navigazioni. Appunti per una biografia. Critica Storica, Firenze, v. 17, p. 55-100, 1980.

DONATTINI, Massimo. Orizzonti geografici dell'editoria italiana (1493-1560). In: REINHARD, Wolfgang; PROSPERI, Adriano (Org.). Il Nuovo mondo nella coscienza italiana e tedesca del Cinquecento. Bologna: Il Mulino, 1992. p. 79-154.

GOODMAN, D. C. Power and Penury. Government, Technology and Science in Philip II's Spain. Cambridge: Cambridge University Press, 1988.

HARVEY, P. Local and Regional Cartography in Medieval Europe. In: HARLEY, J. Brian; WOODWARD, David (Org.). The History of Cartography, 1. Chicago: The Chicago University Press, 1987. p. 464-501.

JOHNSON, Hildegard Binder. Carta Marina: World Geography in Strassburg (1525). Minneapolis: University of Minnesota Press, 1963. 
KARROW, Robert W. Mapmakers of the Sixteenth Century and Their Maps: Bio-bibliographies of the Cartographers of Abraham Ortelius, 1570. Chicago: The Newberry Library, 1993.

LACH, Donald F. Asia in the Making of Europe. Chicago: The Chicago University Press, 1965.

LADNER,Gerhart, Homo Viator: Medieval Ideas on Alienation and Order. Speculum, a journal of medieval studies, Madrid, Universidad Complutense, v. 42, n. 2, p. 233-259, 1967.

MALEKANDTHIL, Pius. The Germans, the Portuguese and India. Münster: Lit, 1999.

MARTINET, Marie-Madelaine. Voyages de découverte et histoire des civilisations dans l'Angleterre de la Renaissance: de la Monarchie Maritime de Dee a la quéte de l'Eldorado par Raleigh. In: CEARD, Jean; MARGOLIN, Jean-Claude. Voyager à la Renaissance. Paris: Maisonneuve \& Larose, 1987. p. 281-301.

MOLLAT, Michel. Le Commerce Maritime Normand. Paris: Plon, 1952.

MYERS, K. The Representation of the New World Phenomena: Visual Epistemology and Gonzalo Fernández De Oviedo's Illustrations. In: WILLIAMS, J.; LEWIS, Robert (Org.). Early Images of Americas: Transfer and Invention. Tucson: University of Arizona Press, 1993, p. 183-214.

OBREGON, Baltasar. Historia de los descubrimientos de Nueva España. Sevilla: Alfar, 1997.

OS CONSTRUTORES do Oriente Português. Lisboa: CNCDP, 1998.

PAUliNO, F. F. (Org.). O testamento de Adão. Lisboa: Comissão Nacional para as Comemorações dos Descobrimentos Portugueses, 1994.

PENROSE, Boies. Travel and Discovery in the Renaissance (1420-1620). Cambridge, MA.: Harvard University Press, 1955.

PESET, José Luis. Ciencia, vida y espacio en Iberoamerica. Madrid: Consejo Superior de Investigaciones Científicas, 1989.

RABELAIS, François. Pantagruel. Euvres complètes, V. Paris: Seuil, 1973.

SACCHI, Duccio. D. Mappe dal Nuovo Mondo: cartografie locali e definizione del territorio in Nuova Spagna, secoli 16-17. Milano: F. Angeli, 1997.

STEELE, Colin. English Interpreters of the Iberian New World: from Purchas to Stevens, a bibliographical study (1603-1726). Oxford: The Dolphin, 1975.

TAZBIR, Jamusz. La conquéte de l'Amérique à la lumière de l'opinion polonaise. Acta Poloniae Historica, Varsóvia, n. 17, p. 5-22, 1968.

TEIXEIRA, Luís. Roteiro de todos os sinais, conbecimentos, fundos, baixos, alturas, e derrotas que bá na costa do Brasil desde o cabo de Santo Agostinbo até ao estreito de Fernão de Magalhães. Ed. fac-sim. Lisboa: Tagol, 1988.

TRINKAUS, C. Renaissance and Discovery. In: CHIAPPELLI, F. (Org.). First Images of America: the Impact of the New World on the Old. Berkeley: University of California Press, 1976.

TUDELA, Juan Pérez de (Org.). Colección documental del Descubrimiento (1470-1506), 3. Madrid: Mapfre, 1994. 
TURNBULL, David. Cartography and Science in Early Modern Europe: Mapping the Construction of Knowledge Spaces. Imago Mundi, London, v. 48, 1996, p. 7-14.

VOGEL, Kaspar. L'écho des Découvertes dans la littérature géographique allemande de la première moitié du XVIe siècle. In: AUBIN, Jean (org.). La Decouverte, le Portugal et l'Europe. Paris: Fondation Gulbenkian, 1990. p. 295-308.

WHITEHOUSE, Eric. The Dieppe Maps and Queensland. Royal Historical Society of Queensland, Brisbane, v. 10, n. 3, p. 127-136, 1977-1978.

ZANDVLIET, Kees. Mapping for Money: Maps, Plans and Topographic Paintings and Their Role in Dutch Overseas Expansion during the 16th and 17th Centuries. Amsterdam: Batavian Lion International, 1998.

Artigo apresentado em 8/2008. Aprovado em 12/2008. 